\title{
A Re-Evaluation of the Privilege Against Adverse Spousal Testimony in the Light of Its Purpose
}

Paul F. Rothstein

Georgetown University Law Center, rothstei@law.georgetown.edu

This paper can be downloaded free of charge from:

https://scholarship.law.georgetown.edu/facpub/2259

https://ssrn.com/abstract=3594856

International and Comparative Law Quarterly, Vol. 12, 1963, 1189-1205.

This open-access article is brought to you by the Georgetown Law Library. Posted with permission of the author. Follow this and additional works at: https://scholarship.law.georgetown.edu/facpub

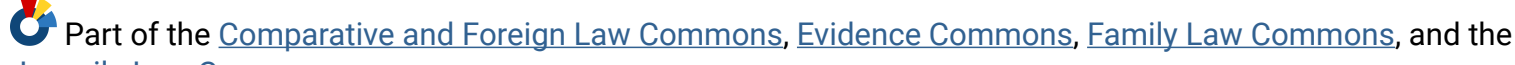
Juvenile Law Commons 


\title{
A RE-EVALUATION OF THE PRIVILEGE AGAINST ADVERSE SPOUSAL TESTIMONY IN THE LIGHT OF ITS PURPOSE
}

\author{
By
}

\section{PaUl F. Rothstein *}

THE recent development in American federal criminal evidence law to be examined and compared with English law in this paper, is a new evolutionary turn taken by the husband-wife privilege against adverse spousal testimony, manifest in the Supreme Court decision of Wyatt v. United States. ${ }^{1}$ The House of Lords, in Rumping v. D.P.P., ${ }^{2}$ just decided, suggests that the English spousal privileges might be susceptible of similar development.

\section{The United States Federal Jurisdiction}

The ancient common law incompetency of one spouse to testify for or against the other in legal proceedings has, in the federal jurisdiction of the United States, eroded into at least two broad privilege principles. ${ }^{3}$ The confidential marital communications

* Lecturer, Faculty of Law, University of Michigan.

1362 U.S. 525 (1960).

2 (1962) 46 Cr.App.R. 398 (H.L.).

3 The erosion has been primarily non-statutory, and substantially follows the English common law, Lord Coke being largely responsible for the substitution of the privileges in place of incompetency. Rule 26 of the Federal Rules of Criminal Procedure, 18 U.S.C. $\$ 3771$ (1951), paraphrases part of the Supreme Court's decision in Funk v. United States, 290 U.S. 371 (1933) (dealing with the history of husband-wife privileges): ". . . the admissibility of evidence, competency, and privileges of witnesses shall be governed by common-law principles, as interpreted by the Federal courts in the light of reason and experience."

A similar, though less clear-cut, erosion of spousal incompetency has taken place among the individual states, with which this paper is not principally concerned. The progress in the states has been primarily statutory: e.g., Ark. Stat. Ann. $\S \S 43-2019,43-2020$ (1947); Ga. Code Ann. $\S \S \quad 26-1410$, 38-1604 (1935); Iowa Code $\S 622.7$ (1950); Miss: Code Ann. $\S 1689$ (1922); Neb. Rev. Stat. $\S 25-1203$ (1948); N.J. Stat. Ann. $\S \S 2,97-4$ (1939); Ohio Gen. Code Ann. \& 1344-2; Okla. Stat. tit. 22 \& 702 (1941); Pa. Stat. Ann. tit. $19 \S 683$ (1930); Tex. Code Crim. Proc. Ann. art. 714 (1938); Ala. Code Ann. tit. $15 \S 311$ (1940); Ariz. Code Ann. $\S 44-2702$ (1939); Cal. Pen. Code $\S 1322$ (1949); Conn. Rev. Gen. Stat. $\$ 8800$ (1949); Mass. Ann. Laws Ch. 233, 320 (1933); Mich. Stat. Ann. \$ 27.916 (1959); Wash. Rev. Stat. Ann. $\S 1214$ (1952); Cal. Code Civ. Proc. $\S 1881$ (1955); Ind. Stat. Ann. $\S \S 2-1713$. 2-1714, 9-1602 (Burns 1955 and Supp. 1960); Me. Rev. Stat. Ch. $135 \$ 22$ (1944); N.Y. Penal Code $\$ 2445$ (1951); Tenn. Code Ann. $\$ 9778$ (1934); Wis. Stat. Ann. $\$ 325.18$ (West 1957); Ill. Rev. Stat. Ch. 38 \$ 734 (1959). (Grouped according to similarity, and within each group, alphabetically. Selection based upon importance, typicality and representative geographic distribution.) See also Turner v. State, 60 Miss. 351 (1882).

See generally 8 Wigmore, Evidence (3rd ed., 1940) $\S \S 2228,2239$ 
privilege ${ }^{4}$ permits the suppression in any civil or criminal case of so much of a spouse's testimony (or a third person's testimony or other perhaps documentary evidence, in some circumstances ${ }^{5}$ ) as may reveal confidences ${ }^{6}$ passed between the spouses by reason of the marital relationship. ${ }^{7}$ The adverse spousal testimony privilege ${ }^{8}$ permits the suppression of all testimony of one spouse against the other, in the latter's criminal prosecution. The distinctions are clear: The first privilege applies only to prevent disclosure of confidential marital communications; the second can entirely prevent the spouse from taking the stand as a witness adverse to the other connubial partner, regardless of the subject-matter of the expected testimony. The first applies in civil and criminal litigation; the second seems to be confined to criminal. The first applies regardless of whether the testimony is for or against the spouse; the second can prevent only testimony adverse to him. The first may cover evidence other than spousal testimony; the second cannot. The first applies whether or not a spouse is party to the litigation; the second requires it. Only the second applies when the testimony does not relate to matters transpiring during the marriage. ${ }^{9}$ Only the second is destroyed by divorce. ${ }^{10}$

(Wigmore is the foremost American authority on evidence); McCormick, Evidence (1954) $\S 68-80 ; 38$ Va. L. Rev. 359 (1952); 56 NW. U.L. Rev. 208 (1961).

4 See (1961) 56 NW. U.L. Rev. 208 for an exhaustive treatment of all aspects of this privilege.

5 See (1961) 56 NW. U.L. Rev. 208. Where the third person overhearing or obtaining knowledge of the contents of the interspousal communication did so with the knowledge, negligence, consent or complicity of a spouse, the confidentiality of the communication, and hence the privilege, may be entirely destroyed; or the privilege to keep a spouse silent may still prevail, but not to keep the third party silent, depending upon the court, upon which spouse (communicant or communicatee) was responsible for the disclosure to the third party, and upon the aggravation of the circumstances. The communicant's and communicatee's privileges may be affected differently, according to their relative responsibility for the disclosure to the third party. These problems frequently arise in an "eavesdropper" context.

s i.e., "confidential communications." A cluster of problems occurs: What is necessary to constitute "confidentiality"? Are acts "communications "? etc. See Hawkins v. United States, 249 F. 2 d 273 (10th Cir. 1957) (acts and events of a prostitution racket not " confidential communications ").

7 Obviously many communications between spouses might also have taken place had they been unmarried. Only communications made in reliance on the marital relationship-i.e., communications that would not have been made but for the relationship-are protected. It is not surprising that many factual problems arise in connection with this determination.

8 See, e.g., United States v. Mitchell. 137 F. 2d 1006 (2d Cir. 1943); Levine v. United States, 163 F. 2d 992 (5th Cir. 1947).

9 This is dictated by the policies behind the privileges, discussed infra at text accompanying footnotes 12-14. See also United States v. Williams, 55 F. Supp. 375 (D. Minn. 1944); Wyatt v. United States, 263 F. 2d 304 (5th Cir. 1959).

10 This too is dictated by the policies of the privileges, discussed infra at text accompanying notes 12-14. See also Pereira v. United States, 202 F. $2 \mathrm{~d} 830$ (5th Cir. 1953). 
At least prior to Wyatt, the general federal rule was that the privileges belong in each case to both spouses ${ }^{11}$ and are exercisable by each alone and independently, regardless of the wishes of the other. This is somewhat logical with respect to the confidential communications privilege, whose policy is to encourage all husbands and wives to entrust marital confidences to their spouses. ${ }^{12}$ For disclosure in court of a confidence might embarrass either or both. ${ }^{13}$ But the policy of the adverse testimony privilege is to preserve normal harmony in the particular marriage involved. ${ }^{14}$ The exercisability problems peculiar to such a policy will largely occupy our attention for the remainder of this paper. ${ }^{15}$ We shall begin by

11 The communicant and communicatee under the confidential marital communications privilege; the witness and the accused under the privilege against adverse spousal testimony.

Contra on the communications privilege: United States v. Mitchell, $137 \mathrm{~F}$. 2d 1006 (2d Cir. 1943), affd. 138 F. 2d 831 (2d Cir. 1943), cert. denied 321 U.S. 794 (1944), rehearing denied 322 U.S. 768 (1944) (Mann Act prosecution : privilege belongs to both but testimony admissible if either one waives).

12 See Hutchins \& Slesinger, "Some Observations on the Law of Evidence: Family Relations," (1929) 13 Minn. L. Rev. 675; McCormick, Evidence (1954) \& 82; and authority collected therein.

13 Even where its communicator desires its disclosure, the communication would, if repeated in court, embarrass its communicatee if it was responsive to and reveals by implication the contents of a prior communication made by and prejudicial to the communicatee. Spousal exchanges are generally a unified transaction with the comments or actions of one spouse intimately linked to, prompted by, and reflective of the other spouse's actions or comments to which they refer. The jury can usually reconstruct both sides of the exchange by hearing one side.

14 See 8 Wigmore, Evidence (3rd $4 \mathrm{~d} ., 1940) \S 2239$ and cases cited throughout this paper.

Notice my use of the words "preserve" and "normal." The privilege does not attempt to produce harmony that is not already there; it is merely intended to prevent judicial interference with existing harmony. This becomes important in our consideration of divorce and separation, infra. Nor should the law attempt to preserve perverted, abnormal, undesirable marriages. This becomes important in our discussion of prostitution, infra.

The marital harmony policy is based upon the perhaps mistaken assumption that the defendant-spouse would resent his spouse for giving adverse testimony, even were that testimony compulsory. Wigmore, supra, suggests that a better policy explanation would be that our natural sense of justice is ontraged at the thought of a person's spouse testifying against him in a criminal prosecution. I find that this begs the question.

Another point to remember here is that the privileges are impediments to the judicial ascertainment of truth, since they may prevent the introduction of competent, reliable and relevant evidence. Therefore, they should be no broader than is absolutely necessitated by some overriding policy consideration.

15 Thus I will substantially abandon further discussion of the confidential marital communications privilege, in spite of its many fascinating problems, having treated it superficially for purposes of distinguishing it from the other husband-wife privilege. Wyatt and Hawkins (discussed infra) concern only the adverse spousal testimony privilege. Both lower courts held the confidential communications privilege inapplicable, in Wyatt because the spousal testimony concerned matters learned by the witness-spouse before the marriage, $263 \mathrm{~F}$. 2d 304 (5th Cir. 1959), and in Hawkins because the testimony concerned the acts and events of a prostitution business, which were not confidential interspousal communications, 249 F. 2d 273 (10th Cir. 1957)). Wyatt and Hawkins tacitly raise anew difficult marital harmony policy questions which thus become currently important. 
discussing how the law should be, not necessarily how it is. Then we can can compare the actual state of the law with this normative paragon. In discussing how the law should be, we will see that different rules concerning who has the privilege should govern in different types of situations, and that it is unrealistic to have a general rule that the privilege belongs to both spouses.

In the very rare situation where the defendant-spouse does not care to raise the privilege, there is little risk of marital discord in taking adverse spousal testimony, regardless of the wishes of the witness-spouse. ${ }^{18}$ Other situations become more complex. Consider first situations in which the only information practicably cognisable by the court concerning harmony in the marriage, is the position taken by both spouses on the privilege issue. Assume also that there is no extraordinary necessity for the testimony. Where the defendant-spouse cares to exclude the testimony (which is virtually always the case), the testimony should be received if the witnessspouse so wishes, inasmuch as the witness-spouse thereby indicates that there is little marital harmony to preserve or salvage, absent other circumstances indicating that the witness's willingness to testify is more likely the manifestation of a temporary spurt of anger or moral compunction, as might be the case where the defendant had seriously wronged the witness shortly before the trial. The witness's unwillingness to testify should be respected because it indicates harmony in the marriage, absent circumstances suggesting that the unwillingness was procured by fear and coercion exerted by the defendant. ${ }^{17}$

16 Cf. 8 Wigmore, Evidence (3rd ed., 1940) $\$ 2241$ where, apparently on the basis of this virtually non-existent situation, Wigmore hastily concludes that since it is resentment by the defendant-spouse that endangers marital harmony, the privilege should belong only to him; for he will resent the taking of testimony only where he raises the privilege, in which case the testimony should be excluded because the violation of his wishes will produce marital discord; but the testimony should be admitted where he does not raise the privilege, because that will not violate his wishes and hence will not produce marital discord. This argument ignores the fact that in many situations, the defendant-spouse will be unable to raise the privilege because of ignorance, mistake, involuntary waiver, loss of privilege, estoppel, untimely invocation, or other operation of law-although he still wishes to exclude the testimiony and will resent its admission. In such a case there may be good grounds for excluding the testimony to save the marriage. The exclusion could then come about either by allowing the witness-spouse to raise the privilege; or by abolishing the legal technicalities disabling the defendant-spouse. Wigmore also forgets that the wishes of the witness-spouse may indicate whether there is any marital harmony to preserve. See following text.

17 The effect of Wigmore's proposal, supra, note 16 , would be almost precisely the opposite. The privilege would belong exclusively to the defendant, and would usually be asserted by him. Thus a spouse willing to testify would ordinarily be prevented from so doing, in spite of the obvious lack of marital harmony. Furthermore, where the defendant lost his privilege through some technicality, an unwilling spouse would be compelled to testify, in spite of the obvious marital harmony. The first-mentioned anomaly is also prevalent under the 
Let us now consider the effect of circumstances which were excluded from discussion in the last paragraph, but which bear on normal marital harmony. We will continue to assume that there is no extraordinary need for the testimony. In certain circumstances, there will be little marital harmony of the type the law strives to preserve: serious wrongs committed by the defendant-spouse against the witness-spouse ${ }^{18}$; prolonged and continuous adultery or prostitution ${ }^{19}$; separation or divorce ${ }^{20}$; sham marriage or marriage contracted in order to acquire the privilege. Under the first and second categories, it is irrelevant whether the wrong is the one being tried in the case at bar. ${ }^{21}$ The "victim" witness-spouse's uncoerced marriage to or cohabitation with the defendant after the wrong, or her voluntary acquiescence in, consent to, or co-operation in the wrong, would tend to nullify the indications of marital strife produced by the wrong. Her unwillingness to testify would not necessarily have this effect. For, unwillingness when there has been such a wrong is more likely the product of fear and coercion wrought by the defendant, than of strong marital ties; unless accompanied by one of the acts of forgiveness just mentioned. Willingness to testify would seem to corroborate the presumption of marital discord arising from the wrong.

It is not judicially feasible to investigate much further than this into whether in a particular case there is in fact marital harmony to preserve, and whether in fact a particular unwillingness to testify is the product of tender love or coercion. The

traditional rule, since both spouses have the privilege. When the defendant loses his privilege by virtue of a technicality, the traditional rule gives proper effect to the wishes of the witness-spouse.

18 This would indicate the nature and strength of feelings between the sponses.

19 This would not only indicate the nature and strength of feelings between the spouses, but would also be relevant in the determination of whether this is the desirable kind of marriage the law strives to preserve.

20 Can divorce and separation be distinguished on the grounds that in separation there is a possibility of reunion? IB it the function of the privilege to belp restore lost union, or at least to prevent the court from further reducing the possibilities of reunion? See second paragraph of note 14 supra. Where the possibility of reunion is so slim, are we justified in barring evidence on the basis of that contingency? See ibid., paragraph 4.

21 To avoid unduly protracted collateral inquiry into wrongs other than those in central issue in the case at Bar, the court could, on the privilege question, limit itself to investigation of convictions or judgments on record, or perhaps to undisputed or indisputable wrongs. Where the judge felt time permitted, and the issue was serious enough, he might consider a limited amount of evidence, perhaps only affidavits, concerning disputed wrongs not of record. The privilege issue should be decided out of the hearing of the jury so that discussion of these collateral wrongs would not prejudice the defendant on the main issue of the litigation. The relevance and probativeness of such collateral wrongs must be strictly limited to the privilege issue. 
courts should rely upon the presumptions that flow from the few readily discoverable circumstances just outlined: the position of the spouses on the admissibility issue, wrongs and immoralities of record or beyond dispute or established by affidavit, obvious characteristics of the marriage, "forgiveness" by cohabitation or marriage, etc. ${ }^{22}$ The presumptions are then likely to be correct quite often, and occasional errors are justified by the judicial economy resulting from so limiting inquiry. ${ }^{23}$

Thus it is possible to first ascertain whether or not there is marital harmony worth preserving in a particular case, before reaching the question of whether there is any special, compelling, peculiar, extraordinary necessity for the testimony. It is clear that according to the seriousness of the charge and the availability of other evidence, the degree of necessity for spousal testimony is continuously variable from case to case, and can be practicably determined in each case by a somewhat ad hoc though necessarily limited examination of the kind of crime and the prosecution's evidence in that case, which inquiry is neither unduly extensive nor judicially uneconomical.

Consequently, one way to decide in each case whether adverse spousal testimony should be admitted or excluded under the privilege, would be to make separate and distinct determinations of marital harmony, and of necessity, and then to balance them against each other. A high degree of marital harmony (determined from the strength of proof, expectations and intensity of normal harmony in the marriage) when coupled with a low degree of necessity, would mean that the testimony stays out. But while degrees of necessity may be roughly ascertained by judges through experience, and have always been so ascertained for purposes of discovery and evidence, our proposed formula for determining marital harmony tends to yield an answer in terms of the existence or non-existence of marital harmony worth saving in a particular

22 It is not too much to ask the court to inquire this far into the privilege matter. After all, spousal testimony is often the crucial evidence, and the privilege question is likely to be very important to both sides. Indeed, in most of the cases cited in this paper, the presence or absence of the spousal testimony was critical.

23 It is frequently said that in order to induce the ordinary non-litigating married couples in the population to rely, in the conduct of their daily matters. on the future availability of the privilege, the privilege as developed in past cases must appear to them absolute, certain of applicability. relatively free from esoteric exceptions, and highly predictable; and that therefore the circum. stances outlined in this text should not be inquired into in each case. But even if the basic premise of this argument is true, the adverse spousal testimony privilege, unlike the marital confidential communications privilege, is unconcerned with inducing reliance, as discussed above in connection with policy. 
marriage, and does not indicate degrees thereof. Any other approach becomes unbelievably cumbersome.

Therefore, admissibility or exclusion under the privilege should be decided in the following manner. Where there is no necessity for the testimony, the ordinary rules of trial procedure concerning superfluous evidence would of course keep it out. Where there is ordinary necessity, admissibility should turn upon the presence or absence of marital harmony worth preserving. Where there is extraordinary necessity, the testimony should come in regardless of the presence or absence of marital harmony. A more precise formulation, including a ranking of categories of cases according to necessity, would then develop. This balancing is not unlike that traditionally engaged in for purposes of qualified privileges, discovery, and ordinary admissibility. ${ }^{24}$ This is a suggested method of approach, heuristic and not exhaustive.

But the courts have not employed these methods of analysis; at least before Wyatt. The privilege resided in both spouses, except in a few situations superficially resembling some of those outlined above. The rules governing these exceptions permitted even less factual examination than advocated herein; and as a result the presumptions underlying the rules were more frequently incorrect as applied to particular cases, than is justifiable in the name of judicial economy resultant from limiting inquiry.

For example, the courts took no cognisance of wrongs committed by one spouse against the other, except for crimes of physical violence ${ }^{25}$ for which the defendant was being tried in the case at Bar, in which event only the defendant was deprived of his privilege, not on the grounds that there was little marital harmony to preserve, but on the spurious grounds of exceptional necessity: that the injured spouse must testify because she was the only witness, which was always assumed to be true despite the frequent surplus of other witnesses. This was called the " special

24 The attorney's work-product privilege articulated in Hickman v. Taylor, 329 U.S. 495 (1947) is almost precisely analogons. See also the privileges surrounding grand jury matters, (1960) $55 \mathrm{NW}$. U.L.Rev. 482, and matters of government interest, (1961) 56 NW. U.L.Rev. 283.

25 The crime charged generally had to be one of physical violence, such as assault or rape, against the person of the witness-spouse. This "special necessity exception," like the general privilege, was substantially lifted by the federal courts from the English common law. Lord Audley's Case (1631) 3 How.St.Tr. 401, is often cited as the classic example of the necessity exception. The defendant hired several ruffians to rape his wife and stood by watching as they carried it out. The wife was allowed to testify over his objections. Cf. Stein v. Bowman, 13 Pet. 209, 38 D.S. 209 (1839) (although a civil case, this is frequently cited as an accurate restatement of the common law necessity exception). 
necessity exception," despite the abundance of cases not comprehended in the exception, in which the witness-spouse's testimony was equally or more necessary. Furthermore, exceptionally necessary testimony remains equally exceptionally necessary regardless of the wishes of the witness; and if anything, the unusual necessity would seem to dictate not that the witness should have the choice to testify, but that she must testify. Therefore, the respect the necessity exception accorded the wishes of the witness-spouse probably was motivated not by considerations of necessity, but by considerations of marital harmony, which was avowedly recognised along with necessity as an operative value. But many things relevant to marital harmony were overlooked, only a few of which need repetition, they all being enumerated above. In these cases of violent crime against the witness-spouse, the unwillingness of the latter to testify should not necessarily be respected because it may be the result of coercion in an embittered marriage, rather than of marital bliss. ${ }^{26}$ Serious spousal wrongs of a nonviolent and/or non-criminal nature, and collateral wrongs not tried in the case at Bar, might nonetheless negate the existence of normal marital harmony and destroy all justification for exclusion, especially when coupled with the witness-spouse's willingness to testify. ${ }^{27}$ Voluntary marriage after, ${ }^{28}$ and/or consent to the wrong might restore harmony and justification for exclusion, particularly when coupled with uncoerced unwillingness to testify. ${ }^{29}$

26 Wyatt, discussed infra, intimates that, the trial involving a serious crime by the defendant-spouse against the witness-spouse, the unwillingness to testify was probably coerced by the defendant. But such insight was inappropriate in that case, where other feasibly cognisable facts indicated the absence of coercion. See note 29 infra, first paragraph and accompanying text.

27 For a serious failure to recognise this, see e.g., Hawkins v. United States, 358 U.S. 74 (1958), discussed infra at text accompanying notes 34-36.

28 The necessity exception deprives the defendant of his privilege even when the marriage between the spouses took place after the crime. United States $\nabla$. Williams, 55 F.Supp. 375 (D. Minn. 1944). Contra: United States v. Gwynne, 209 Fed. 993 (E.D. Pa. 1914).

20 All of these factors were present in Wyatt, and yet the testimony was still excluded.

In summary, the necessity exception improperly treats the witness's willingness or unwillingness to testify, where there has been a serious wrong committed by the defendant against the witness. In a necessity exception case where that witness is willing to testify, the traditional rule properly allows the testimony. But where, in the same situation, the witness is unwilling, that wish is, improperly, respected automatically under the rule. Where the wrong by the defendant against the witness is serious but does not come within the literal terms of the necessity exception, the defendant is, quite irrationally, able to defeat the willingness of the witness to testify. Unwillingness to testify in such a case is, improperly, respected.

For the suggestion that the danger of perjury is not the reason why the necessity exception perraits the witness-spouse the option, see note 58 infra.

It might be noted that the necessity exception ignores degree of social necessity for conviction in that non-disclosure is more likely to prevail in cases where the crime is not against a spouse but against members of the public (in which 
Only in extremely compelling and aggravated circumstances did the courts find marriages to be sham or contracted solely for the purposes of acquiring the privilege, in which cases the privilege was apparently denied both spouses, on the formal reasoning that there had been no real marriage at all and, therefore, one of the technical prerequisites for the operation of the privilege was not satisfied. ${ }^{30}$ Similarly, divorce destroyed the marriage relationship and the privileges of both spouses along with it. ${ }^{31}$ Behind these formalisms, there was a judicial recognition that in those particular circumstances it was futile to attempt to preserve a normal harmonious marriage, and therefore neither spouse should be able to bar the testimony.

Traditionally, prostitution was considered only in so far as it came within the literal terms of the "necessity exception": that is, if the husband prostituted the wife and that was the crime for which he was being tried, the husband lost his privilege. ${ }^{32}$

case both spouses have the option to invoke the privilege), than in cases where the crime is against the witness-spouse (in which case only one spouse bas the privilege). And yet it would seem more important to gain full disclosure in the former case toward the end that criminals perpetrating crimes with the most widespread effects be convicted.

There is a certain superficial justice about permitting the victim-spouse to damn or acquit her defendant-spouse where the incidence of the crime was primarily against her rather than the public. Is this consistent with the rarity of applicability of the doctrine of condonation (which holds that in some cases the consent or ratification by the victim abrogates any criminal responsibility)? Is the court in a criminal action as distinguished from a civil action concerned with redressing individuals, or with social retributive justice and deterrence?

30 Lutwak v. United States, 344 U.S. 604 (1953) (prosecution for violation of the War Brides Act, where three American service women were paid to go to France and go through sham marriage ceremonies with three Frenchmen to enable the latter to enter the country; "wives" allowed to testify); United States v. Graham, 87 F.Supp. 237 (E.D. Mich. 1949) (prosecution for interstate transportation of money feloniously stolen from defendant's wife; wife permitted to testify over defendant's objection; marriage contracted merely to facilitate the crime); Pereira v. United States, 202 F. 2d 830 (5th Cir. 1953) (prosecution for mail fraud committed against defendant's spouse; witness-spouse permitted to testify over defendant's objections; marriage a pretence to defendant, contracted to aid the scheme). (Since only the defendant raised the privilege in these cases, we cannot be certain whether the privilege wonld have been denied both spouses; but the reasoning suggests that it would. These cases may be considered merely standard necessity exception cases.) But see United States v. Walker, 176 F. 2d 564 (2d Cir. 1949) (defendant, a professional "con-man" who was in the habit of preying on elderly women's money, occasionally " marrying" them if necessary, accidentally legally married the witness-spouse, but never lived with her, considering it a sham and marrying other women subsequently; yet the court held the volunteered testimony of this "legal" wife inadmissible in the prosecution for one of the later offences).

31 Periera v. United States, 202 F. 2d 830 (5th Cir. 1953).

32 The Mann Act, 62 Stat. 812 (1948) as amended 63 Stat. 96, 18 U.S.C. 2421 (1951) punishes interstate transportation of women for immoral purposes. Its violation is the only significant crime involving prostitution cognisable by the federal trial courts. The federal opinions have usually held that in Mann Act prosecutions, where the defendant's wife has been the woman transported, 
This excluded many other sorts of prostitution which might have indicated that an attempt to preserve a normal harmonious marital relationship by suppressing the adverse spousal testimony, would be futile. ${ }^{33}$

The absurdity of the federal rule and its exceptions prior to Wyatt is well illustrated by the result in the Supreme Court decision of Hawkins v. United States. ${ }^{84}$ In a prosecution of the husband for a crime not against the wife, the wife was, in the name of marital harmony, not permitted to testify against the husband; despite the fact that there was plainly no marital harmony (and certainly none of the type the law strives to preserve) since the wife roanted to testify, and was a continuing prostitute, being prostituted by her husband in violation of law. ${ }^{85}$ As noted, it would have been judicially practicable to take cognisance of these obvious facts. ${ }^{36}$ Yet the husband did not lose his privilege, because the crime, not being against his wife, did not come within the necessity exception; and hence he was able to keep the wife off the stand.

Shortly thereafter, the Supreme Court decided Wyatt v. United States, ${ }^{37}$ a prosecution against a husband for prostituting his wife. ${ }^{38}$ The wife was forced to testify against the husband over her and his timely objections, and the Supreme Court affirmed the propriety of the trial court's action. While the crime charged was plainly within the traditional necessity exception, ${ }^{30}$ the court went beyond that precedent in depriving both spouses of their privilege. ${ }^{40}$ The

she is competent to testify against her husband, and may do so over his objections, if she so desires. The transportation for immoral purposes is considered a crime of physical violence against the person of the wife, bringing it within the necessity exception, despite the lack of bodily injury of the type necessary at common law, and despite any consent the wife may have given. The moral injury is considered sufficient. Pappas v. United States, 241 Fed. 665 (9th Cir. 1917); Shores v. United States, 174 F. 2d 830 (8th Cir. 1949); United States v. Williams, 55 F. Supp. 375 (D. Minn. 1944). In these cases the wife volunteered testimony, and the courts held that defendant could not bar it. There was no question concerning compelling the wife to testify. Certain tacit inferences rather:vaguely hinting that the wife might be compellable, in the latter two cases. ere merely dictum, the decisions being expressly reached upon the basis of the old necessity exception.

33 e.g., Hawkins v. United States, 358 U.S. 74 (1958), discussed infra.

34358 U.S. 74 (1958).

35 The crime tried in the case at Bar was a violation of the Mann Act, but the wife was not the woman transported. The prostitution of the wife was a separate offence not directly involved in the case at Bar.

The lack of normal marital relationship and harmony is made obvious by the facts that the defendant during trial referred to the witness as his "exwife" and testified that they had never lived together very much. 358 U.S. 74, 82; 249 F. 2d 735 (10th Cir. 1957).

36 See text preceding note 23 supra.

37362 U.S. $525(1960)$.

s8 Under the Mann Act.

39 See note 32 supra.

40 Although the court purported to rely on the vague dicta mentioned at the end of note 33 supra. 
result at first seems to be as egregious as that in Harekins, for the opposite reason. For here the court permitted testimony that could damage a marriage that was obviously strong and harmonious, ${ }^{41}$ as evidenced by the facts that the wife married the husband after the alleged wrong, the wife zealously managed the prostitution business as the dominant partner, ${ }^{42}$ and she did not wish to testify-all of which would more than negate presumptions of coercion ${ }^{43}$ and marital strife from the wrong, and all of which would seem to be conveniently cognisable by the court, as noted above. ${ }^{44}$ The failure to consider these facts, then, cannot reasonably be ascribed to administrative practicability. ${ }^{45}$ Nor can it be ascribed to a complete loss of confidence in the marital harmony policy with a consequent abolition of the entire privilege; because marital harmony is expressly mentioned as the justification for the privilege, ${ }^{46}$ and the whole tone of the opinion seems to imply some limit on its own scope, confining it somehow to this case or type of case. ${ }^{47}$ Nor can the decision be reasonably ascribed to an expansion in this peculiar situation of the effect of the necessity exception on the grounds that this case or type of case involves extra-special necessity for testimony; because necessity is not mentioned. No investigation of need in this particular case was made, although a rudimentary inquiry of this kind is not unduly inconvenient ${ }^{48}$; and there is nothing to distinguish the necessity in this type of case from the necessity in other equally or more serious prosecutions, so therefore the expanded necessity exception would tend to consume the general privilege rule, contrary to the limiting tone of the

41 On first glance it appears that Hawkins is effectively overruled. For if the court is willing to disrupt the firmer marriage in Wyatt by allowing the testimony, then a fortiori it would be willing to disrupt the infirm marriage in Hawkins by allowing the testimony. Less marital damage would be done by permitting the testimony in Hawkins than was actually done in Wyatt.

42 Testimony clearly indicated that the woman made all the arrangements with the hotel bellboy, and discussed business opportunities with him, while the husband spent most of his time in the room, drinking.

$43 \mathrm{Cf}$. text accompanying notes 54 to 56 infra.

44 Note 23 supra and text preceding it.

45 The court does, however, say (at page 530): "To make matters turn upon $a d$ hoc inquiries into the actual state of mind of particular women . . . is hardly an acceptable solution." But we may take this as imposing no greater limits on inquiry than advocated in this paper at note 23 supra and text preceding it.

46 The opinion mentions the marital harmony policy as the basis of the privilege, at p. 527. An abandonment of the marital harmony policy would of course be totally inconsistent with Hawkins.

47 "We deal here only with a Mann Act prosecution, and intimate no view on the applicability of the privilege of either a party or a witness similarly circumstanced in other situations." Opinion, p. 531. This is important in my textual discussion that follows.

48 See text following note 23 supra. 
opinion. ${ }^{4 \theta}$ One possibility is that the court accepted, on the authority of cases holding Mann Act prosecutions to be within the necessity exception, that there was the special necessity for the testimony here that is always incident upon necessity exception prosecutions ${ }^{50}$; and held that, contrary to authority, special necessity is unaffected by the wishes of the witness, ${ }^{51}$ and therefore the testimony should always be taken in necessity exception cases regardless of those wishes, marital harmony being irrelevant in the face of necessity. However, if the court were reformulating the entire necessity exception, it would have gone all the way and penetrated the fiction that there was special necessity here. At any rate, the court disclaims any such broad revision of the whole necessity exception. ${ }^{52}$ The court also rejects the suggestion that witness-spouses cannot own the privilege. ${ }^{53}$

The rationale actually articulated by the court is that the Mann Act, intended to protect defenceless females from subjugation, irrebuttably presumes that the woman transported and prostituted had no will of her own and was completely dominated by and

49 However, this rationale would have the advantage of tending to reconcile Hawkins and Wyatt. A perusal of both cases reveals a greater availability of other evidence and testimony in the former, and hence a greater necessity for the spousal testimony in the latter. Is this assessment properly made at the appellate level after all evidence is revealed? The court makes no mention of necessity at all, either with respect to the seriousness of the offence or the amount and nature of the testimony. This is quite understandable.

It could conceivably be suggested, somewhat unconvincingly, that Mann Act cases can be distinguished from ordinary necessity exception cases in that there is a greater social necessity for conviction of criminals perpetrating crimes of the Mann Act variety which have detrimental effects primarily upon members of the general public, than for conviction of criminals who hurt primarily their spouses. Is this consistent with the statements in the opinion to the effect that the Mann Act offence is primarily against the transportee (see text accompanying note 54 infra), who was the witnessspouse in this case? Does society really have more of an interest in preventing prostitution than in preventing crimes of violence? Has not the responsible legislative authority decided the issue of social objectionability in drafting the criminal proscription and a penalty of a certain severity? Is the individual incidence of conduct a criminal or civil concern? Are not all crimes socially noxious? Is the suggested function properly judicial when arrogated to a court sitting in criminal jurisdiction?

50 This would distinguish Hawkins (which was not a traditional necessity exception prosecution).

51 Compare this entire rationale with the material presented in text, several sentences preceding note 26 , supra.

52 "Neither can we hold that, whenever the privilege is unavailable to the party, it is ipso facto lost to the witness as well. It is a question in each case, or in each category of cases, whether, in light of the reason which has led to a refusal to recognise the party's privilege, the witness should be held compellable. Certainly we would not be justified in laying down a general rule that both privileges stand or fall together." The opinion, p. 529.

53 See the opinion at p. 529: "We decline to accept the view that the privilege is that of the party alone." $C f$. note 16 supra. 
subordinated to the will of the accused. ${ }^{54}$ Thus the court concludes that the marriage and refusal to testify were coerced by and manifested the will of the husband, and were not the voluntary acts of the wife. They were his will alone, not hers. Hence, either the marriage was sham, in which case the privilege is inapplicable, ${ }^{55}$ or the ostensible assertion of the privilege by the wife was in reality rather the indirect and improper assertion by the husband of a privilege he had lost through the ordinary operation of the standard necessity exception as traditionally applied in Mann Act cases, although a privilege still validly subsisted in the wife and could have been exercised, had she sufficient freedom of will. ${ }^{56}$

The reasoning is obviously fallacious. The facts of the case indicated that the wife dominated the husband. ${ }^{57}$ Even if a general irrebuttable presumption of subordination of the transported by the transporter in this type of prosecution is justifiable on the grounds of expediency and ninety-times-out-of-one-hundred accuracy despite occasional discrepancies, the presumption certainly pertains only to the inability to resist the transportation and immoralities, and is not intended to imply an across-the-board lack of will for all purposes, such as testimony and marriage. Furthermore, if such a general presumption is to prevail in Mann Act cases, there is no reason why it should not apply to other equally or more serious crimes involving the complicity of the spouse. The decision would not seem to be intended to have such far-reaching consequences. Finally, a general presumption of this nature would appear to suggest that the compelled testimony will very likely be perjured, and should not be admitted. ${ }^{58}$

It is difficult to believe that so palpably unacceptable a rationale motivated that venerable court. A truer, though unarticulated and

34 Denning v. United States, 247 Fed. 463 (5th Cir. 1918), one of the earliest cases construing the Mann Act and describing the reasoning behind it, is cited for this proposition, as are the Congressional debates preceding the enactment. See p. 530 of the Wyatt opinion.

55 See note 30 supra and accompanying text. This rationale would seem to distinguish Hawkins, where the wife did not technically come within the presumption of the Mann Act. But there may have been as much reason to invoke a similar presumption of lack of independent will in Hawkins. The lack of will rendering the marriage sham is not specifically emphasised in Wyatt. Rather, the lack of will to exercise the privilege is.

56 This rationale would distinguish Hawlins.

57 See note 42 supra.

58 The standard necessity exception is occasionally defended on the ground that even though the accused has lost his privilege, the witness-spouse must retain hers to avoid the perjury that compelled testimony is likely to entail in such a situation. But there is always the danger of perjury when testimony is compelled, and especially is this true where one sibling is compelled to testify against another in the same immediate family or against his own parent, or a parent against his own child, or any relative against relative, or friend against friend. And yet, such witnesses are not accorded privileges. 
therefore extra-legal, explanation of the result must be discoverable, toward the end that future behaviour of the court may be to some extent predicted. ${ }^{50}$ I suspect that the decision was actually dictated by considerations concerning the nature of prostitution. As indicated, many factors suggested that the marriage was strongly cohesive ${ }^{60}$ so that the case was not a particularly compelling one for establishing a general irrebuttable presumption against marital harmony where there is prostitution of this kind. Rather, I cannot help thinking that the court felt that these were not the type of marriages to be fostered. ${ }^{61}$ If such is the case, it would matter little whether the spousal prostitution were involved in the case at Bar, as in Wyatt, or collaterally, as in Hawkins (which on this rationale would be reversed) ${ }^{62}$; and whether the Mann Act were in any way involved.

Other serious spousal immoralities less distributive and commercial than prostitution (such as pre-marital relations between the now spouses, which incidentally is punishable under the Mann Act when it motivates the interstate trip ${ }^{03}$ ) would not necessarily have the same consequence.

50 This may be somewhat reminiscent of Lord Denning, who feels that too much attention can be paid to the expressed reasoning in a decision, rather than the result. See his address before the Oxford Law Society, University College, Michaelmas Term, 1961.

60 See text accompanying notes $41-44$ supra.

$61 C f$. second paragraph of note 14 supra.

The language at p. 527 of the opinion suggests the conclusion in the text accompanying this note: "... [I]t cannot be seriously argued that one who has committed this "shameless offense against wifehood". . . should be permitted ... [to invoke] an interest founded on the marital relation or the desire of the law to protect it."

Again, at p. 529: "Where a man has prostituted his own wife, he has committed an offense against both her and the marital relationship. . . ."

(This feeling on the part of the court may have been coupled with the feeling that somehow there was special necessity for the testimony here; and that therefore an undesirable marriage should not be preserved at least where there is special necessity for the testimony. But we have seen that there was no special necessity revealed in this case; and any suspicion that there was derives from the fiction propagated by stare decisis that necessity exception prosecutions always involve special necessity. Furthermore, the court does not mention necessity or the social desirability of conviction.)

62 Actuslly, it is better if the prostitution in issue on the privilege question is not part of the ultimate issue of the case. (The best of such situations occurs if the prostitution in issue on the privilege question has already been collaterally determined in another judicial proceeding.) Nevertheless, it is not unheard of for the trial judge to make a preliminary decision, for evidentiary admission or exclusion purposes, of matters ultimately substantively in issue, even though the jury may later decide differently than the judge (which would not in any way affect the propriety of the judge's ruling or compel its reversal).

It might be interesting to note at this point that the presumptions underlying the standard necessity exception, and the presumption of lack of independent will supposedly indulged by the Wyatt court, assume that the accused is guilty of the crime even before the jury has heard the evidence and reached a decision.

03 See first sentence of note 32 supra. 


\section{ENglish Law}

If this is indeed the " rationale" behind Wyatt, it is sound, and could be transplanted advantageously into the English law of evidentiary privilege, which would be congenial to it because this area of the law is basically similar on both sides of the Atlantic. ${ }^{84}$ However, the transplanting would probably have to be statutory, since in England the erosion of the old common law incompetency into the two spousal privileges is largely codified. ${ }^{65}$ The Wyatt principle could be incorporated into both the confidential interspousal communications privilege and the adverse spousal testimony privilege, since it appears that in England the policy of both is to preserve the instant marriage, contrary to the American rule, where this is the policy only of the latter.

64 For the English law on the privileges, see note 65 infra. Regarding English offences against sexual morality which could produce the same effect that is discussed herein in connection with the American ]aw, above, see Sexual Offences Act, 1956; Street Offences Act, 1959; R. v. Chapman [1959] 1 Q.B. 100 (C.C.A.) (indicates that the law recognises sexual immorality alone as unlawful for some purposes); Shaw v. D.P.P. [1961] 2 W.L.R. 897 (H.L.) (living off the earnings of prostitution; the "Ladies Directory Case").

65 Matrimonial communications: "No husband shall be compellable to disclose any communication made to him by his wife during the marriage, and no wife shall be compellable to disclose any communication made to her by her husband during marriage."

Evidence Amendment Act, 1853, 8. 3; Criminal Evidence Act, 1898, 8. 1 (d); Workmen's Compensation (Supplementation) Act, 1951, 8. 4 (5) proviso. See aiso Shenton v. Tyler [1939] Ch. 620 and criticism thereof by the late Sir William Holdsworth, in (1939) 56 L.Q.R. 137. The extent to which evidence other than testimony, such as letters or documents, may be suppressed on the grounds that it reveals a matrimonial communication, is discussed infra in connection with Rumping v. D.P.P.

Adverse spousal testimony: Criminal Evidence Act, $1898, \mathrm{ss} .1$ (c), 4; and other more particular Acts which make certain minor inroads upon this Act in a few selected situations, to be mentioned infra. A spouse is incompetent to testify for the prosecution of his or her consort, unless the latter gives permission, in which case the former can testify but is not generally compellable. It is easily seen that this substantially amounts to the traditional American federal adverse spousal testimony privilege belonging to both spouses, with the exception that the English defendant-spouse's privilege is automatically exercised unless he waives it voluntarily. By abolishing, to some extent, involuntary waiver, the English rule probably aids the marital harmony policy by eliminating one source of marital friction that is present in the American rule. The English rule preserves the error, noted above as a failing of the American rule, of generally granting the privilege to both spouses without legislative, let alone individual judicial, consideration of the factors mentioned as important in the text accompanying notes 16-25 supra. But some progress beyond the American view has been made by the English along these lines. For the defendant's privilege is destroyed not only if the case falls into one of the crimes categorised under the common law necessity exception described above, but also if it falls into one or more of certain other statutorily enumerated categories of crime, which presumably were selected roughly on the basis of seriousness, offensiveness, and desirability of and likelihood of preserving the marriage. (However, these considerations lead to a deprivation of both spouses of their privilege only in a strictly confined group of instances, discussed infra.) In general they are offences involving either sexual. immorality, disturbance of the family relationship, or harm to youngsters; which adds support to the thesis advanced in this paper. 
Although the English authorities frequently repeat that the policy behind the privilege preserving the confidentiality of marital communications is the same as in the federal jurisdiction of the United States, namely, to encourage all husbands and wives to communicate freely with their consorts, ${ }^{60}$ this is apparently belied by the facts that the privilege belongs solely to and may be invoked only by the spouse receiving the communication, that the privilege is lost upon divorce, that the privilege covers communications not originally intended as confidential or which would have been made regardless of the marital relation, and that third persons present at or overhearing the communication generally cannot be kept silent under the privilege. ${ }^{67}$ The latter is definitely one import of the House of Lords decision in Rumping v. D.P.P., ${ }^{08}$ holding proper the admissibility of a letter, from the defendant husband to his wife, that contained a virtual confession of murder and which had been intercepted and held by the police. The court indicated that the situation might be otherwise, had the wife received the letter without interception. ${ }^{69}$

Under the English privilege against adverse spousal testimony, there are a few isolated types of cases in which both spouses are deprived of the privilege, somewhat after the fashion of the Wyatt principle. Thus the legislature seems to have decided that in the trial of interspousal thefts under the Married Women's Property Act, a marriage which facilitates the stealing by one consort of the other's property, is not to be encouraged at the expense of endangering the chances of conviction of such offenders ${ }^{70}$; and future legislative encroachments of this nature are not impossible. Furthermore, where the witness-spouse would have been competent to testify at ancient common law, neither she nor her spouse can assert the privilege, ${ }^{71}$ since the privilege is but an erosion of the old incompetency. This may afford the courts some latitude to apply a type of Wyatt approach. Certainly the English courts

${ }_{66}$ See, e.g., Phipson, Evidence (1952), p. 213 and cases cited therein. See also Rumping v. D.P.P., infra.

87 In addition to the material cited in the first part of note 65 supra, see O'Connor v. Marjoribanks (1842) 4 M. \& G. 435 (on the confidentiality and marital relationship points); Doker v. Hasler (1824) Ry. \& M. 198 (semble); Cowley v. C., The Times, Jan. 20, 1897 (semble); R. v. Smithies (1832) 5 C. \& P. 332 (third person point); R. v. Bartlett (1837) 7 C. \& P. 832 (semble); Hamp v. Robinson (1855) 16 L.T. 29 (semble). On all the points compare the American federal privilege, at notes 4 to 7 supra and accompanying text.

68 (1962) 46 Cr.App.R. 398 (H.L.).

69 Compare text accompanying note 5 supra.

70 Married Women's Property Act, 1884, s. 1 (either consort is an admissible and, except when defendant, a compellable witness).

71 R. v. Lapworth [1931] 1 K.B. 117 (C.C.A.) (forcible or fraudulent marriage, "spouse" competent at common law, no privilege). A bigamous marriage is the same. See note 72 infra for rationale. 
are free to apply the "lack of independent will," "sham marriage," 72 and " indirect assertion by the dominant spouse of a lost privilege" analyses, enunciated in Wyatt, wherever appropriate. ${ }^{\mathbf{3}}$

\section{ConClusion}

The Wyatt case presents a modification of the traditional privilege against adverse spousal testimony, which modification, if founded upon the articulated rationale, makes little sense in that case, but conceivably might be appropriate in a proper English or American case; but which, if founded upon a deeper social policy, was properly applied in that case, and has broader implications concerning not only the adverse spousal testimony privilege, but, in England, the confidential marital communications privilege as well.

72 In forcible or fraudulent marriage, neither spouse has the privilege, Lapworth, supra, note 71. One of the requirements for the ancient incompetency and the modern privilege, namely, a bona fide marriage, is missing. See also $R$. v. London (Lord Mayor) (1886) 16 Q.B.D. 772, 775-776; Case of Wakefield (1827) 2 Lewin C.C. 279 ; D.P.P. v. Blady [1912] 2 K.B. 89, 92; Leach v. R. [1912] A.C. 305 (H.L.); R. v. Blanchard [1952] 1 All E.R. 114 (C.A.). On the same rationale, the second marriage in a case of bigamy is not a bona fide marriage, and the second "spouse" is not a spouse and was competent at common law, so that neither "spouse" has the privilege. Phipson, Evidence (1952), p. 478. Cf. R. v. Green (1949) 63 J.P. 745.

73 Crimes somewhat analogous to violations of the Mann Act in which it might be successfully argued that there was a subordination of the will are, e.g., procurement (Sexual Offences Act, 1956, ss. 22, 23), taking a young girl from her parents for purposes of sexual immorality $(R$. v. Chapman [1959] 1 Q.B. 100 (C.C.A.)), living off the earnings of prostitution (Shaw v. D.P.P. [1961] 2 W.L.R. 897 (H.L.)), defilement of young girls (1956 Act, s. 5), abduction (s. 6), and other such offences, against young people or mental deficients. 